\title{
Kajian Bahasa Rupa Berdasar Rekaman Video Pergelaran Wayang Kulit Purwa dalam Lakon 'Parta Krama'
}

\author{
Ismurdyahwati ${ }^{1}$, Setiawan Sabana ${ }^{2}$, Primadi $^{2}$ \& Priyanto $^{2}$ \\ ${ }^{1}$ Universitas PGRI Adibuana-Surabaya \\ ${ }^{2}$ Fakultas Senirupa dan Desain-ITB
}

\begin{abstract}
The shadow effect of leather puppet's movements on the screen can be used to determine performance quality of the puppet and the creativity of a puppeteer. The most important tools to perform the shadows effect are blencong (traditional lamps), kelir (screen) and debog (banana tree trunk). Therefore, many of the terminologies used in this study refers to terminologies used in the puppet performance of Javanese customs, particularly Yogyakarta's style, which originates from the School of puppet play performance of Habirandha in Yogyakarta - Indonesia.

The study observed detailed 'movement' of Purwa in Yogyakarta's style, as each detailed movement possesses its own story that determines the plays and body language of character in the leather puppet performance. To observe facial expression of puppet characters, the study uses the $11^{\text {th }}$ sequence and 70 facial expressions (gambar) of movement in the Kedhaton Dwarawati acts. The study observes that in each "space" and "time" of plays there are stories of movement, which can be used to describe the visual language of shadow leather-puppet performance.
\end{abstract}

Keywords: leather puppet; shadow play; visual language.

\section{$1 \quad$ Pendahuluan}

\subsection{Wayang Kulit Purwa Yogyakarta}

Pergelaran wayang kulit yang diamati dalam tulisan ini adalah bentuk gerak bayangan dari arah kelir (permainan bayangan/shadow play) ${ }^{1}$ melalui sinar lampu blencong ${ }^{2}$ sebagai objek penelitian. Aspek 'gerak' tersebut berasal dari gambar-gambar bayangan yang dimainkan oleh dalang sebagai penentu cerita. Aspek 'gerak' ini, di dunia pedalangan dikenal dengan sebuatan "sabetan"

\footnotetext{
1 Shadow play merupakan teknik kuno untuk bercerita dan hiburan dalam format permainan bayangan.

${ }^{2}$ Meskipun aslinya lampu blencong menggunakan minyak untuk menerangi layar/kelir seperti pagelaran wayang kulit di Bali hingga kini. Tapi di Jawa lampu blencong sudah menggunakan listrik, dan istilahnya tetap dengan nama lampu blencong.
}

Received September $7^{\text {th }} 2007$, Revised November $26^{\text {th }} 2007$, Accepted for publication December $12^{\text {th }} 2007$. 
(Jawa) yang berhubungan dengan pakeliran segala lakon wayang yang dilayarkan/dikelirkan sebagai makna "jagad" [1] dan lakon perjalanan cerita wayang atau rentetan peristiwa wayang [2]. Penyelenggaraan pergelaran wayang kulit dipersiapkan dengan ketentuan dari pelaksanaan pergelaran itu sendiri, seperti kompetensi dalang dalam menampilkan mutu suara dan artikulasi.

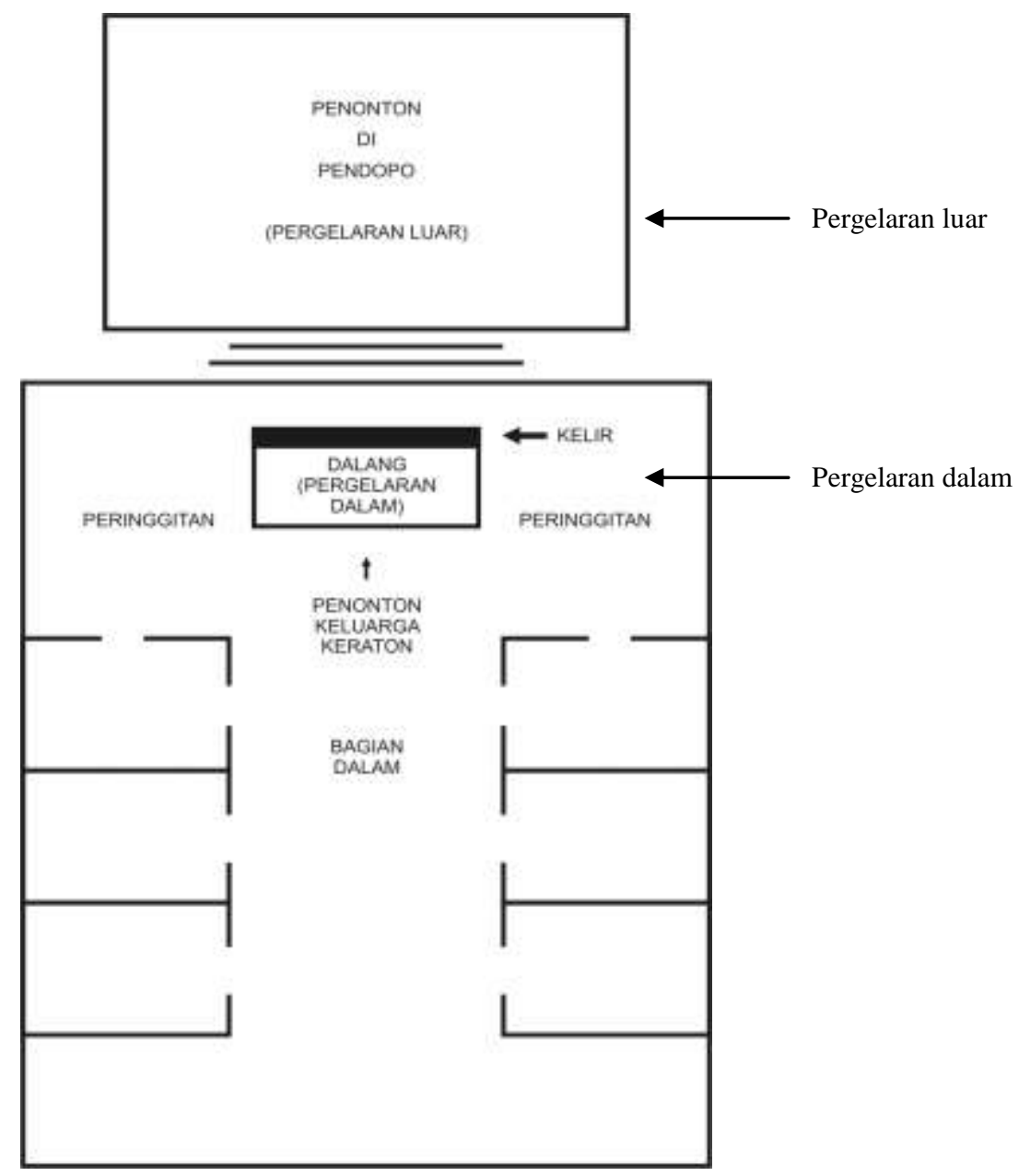

Gambar 1 Denah lokasi pergelaran luar dan pergelaran dalam. (Laporan penelitian. Primadi Tabrani, dkk. 1998)

Hingga saat ini pakeliran gaya tradisi Yogyakarta, masih difungsikan seperti dimasa-masa sebelumnya yaitu, pada: 
1. perhelatan keluarga yang berkaitan dengan daur hidup (sepasaran bayi, selapanan bayi, tetakan, tetesan, pernikahan, tingkeban, nyewu dan sebagainya.

2. Adat istiadat (contoh: ruwatan dan nyadran atau bersih desa).

3. Kaulan atau nazar atau syukuran. Meskipun begitu unsur hiburan juga disertakan, seperti dalam adegan gara-gara.

Untuk selanjutnya digunakan istilah gaya Yogyakarta, karena penggunaan istilah 'gaya' menyangkut gaya tradisi pedalangan yang berkaitan dengan teknis ketrampilan menggerakan wayang yang dimiliki dalang. Metoda pengamatan dalam penelitian menggunakan bahan rekaman dengan teknik kamera dalam posisi 'diam' - tidak bergerak - sehingga hasil rekamannya persis sama dengan pagelaran asli dilihat dari posisi penonton. ${ }^{4}$

Penelitian dan pengkajian wayang kulit sebelumnya, antara lain dilakukan oleh Moerdowo, dalam Reflections on Indonesian Art and Culture, mengklasifikasi boneka wayang menurut kepangkatan, jenis kelamin dan asal-usul penggunaan istilah umum [3]. Victoria M. Clara van Groenendael meneliti tentang dalang sebagai penghidup cerita, dengan judul Dalang di Balik Wayang ${ }^{5}$ [4]. Penelitian ini mengungkapkan tentang dalang dalam posisi yang sentral, dianggap sebagai sutradara dan sekaligus sebagai pelaku utama dalam pertunjukan wayang kulit. Dalang sebagai penghidup cerita selain memiliki pengetahuan teknik-teknik memainkan gerak wayang juga menguasai teknik menancapkan wayang dan tokoh wayang dalam suatu panggung pertunjukan, seperti wayang simpingan atau wayang disimping ${ }^{6}$, merupakan kelompok

3 Adegan gara-gara, berisi para punakawan yang sedang bergembira sambil bernyanyi dan menari dalam waktu senggang, yang biasa digunakan untuk menghibur para penonton, sehabis adegan tegang, contoh : adegan perang.

${ }^{4}$ Pagelaran luar, merupakan istilah lain dari pagelaran dari arah belakang kelir (dari arah bayangan)

5 Judul asli The Dalang behind the Wayang - The Role of the Surakarta and the Yogyakarta Dalang in Indonesia - Javanese Society. Diterbitkan sebagai No.114 seri Verhandelingen van het KITLV. 1985, Koninklijk Instituut voor Taal - land enVolkenkunde, Leiden.

6 Wayang simpingan ini diletakkan dan disimpan berdasarkan derajat kedudukan status tokoh wayang termasuk penampilan fisik seperti ukuran badan, gaya rambut, kemiringan wajah, dan seterusnya. Tempat penyimpanan yang lain adalah, kotak penyimpanan (peti) atau kotak (semacam bingkai) dari bambu, yang oleh para dalang disebut wayang dhudhahan atau wayang dugangan (wayang dhudhahan atau dugangan merupakan kelompok wayang yang tidak disimping di batang pisang). Wayang dugangan merupakan wayang yang posisi kaki wayang berjalan. 
wayang yang dipasang berderet di kiri dan kanan panggung pentas pada saat pergelaran

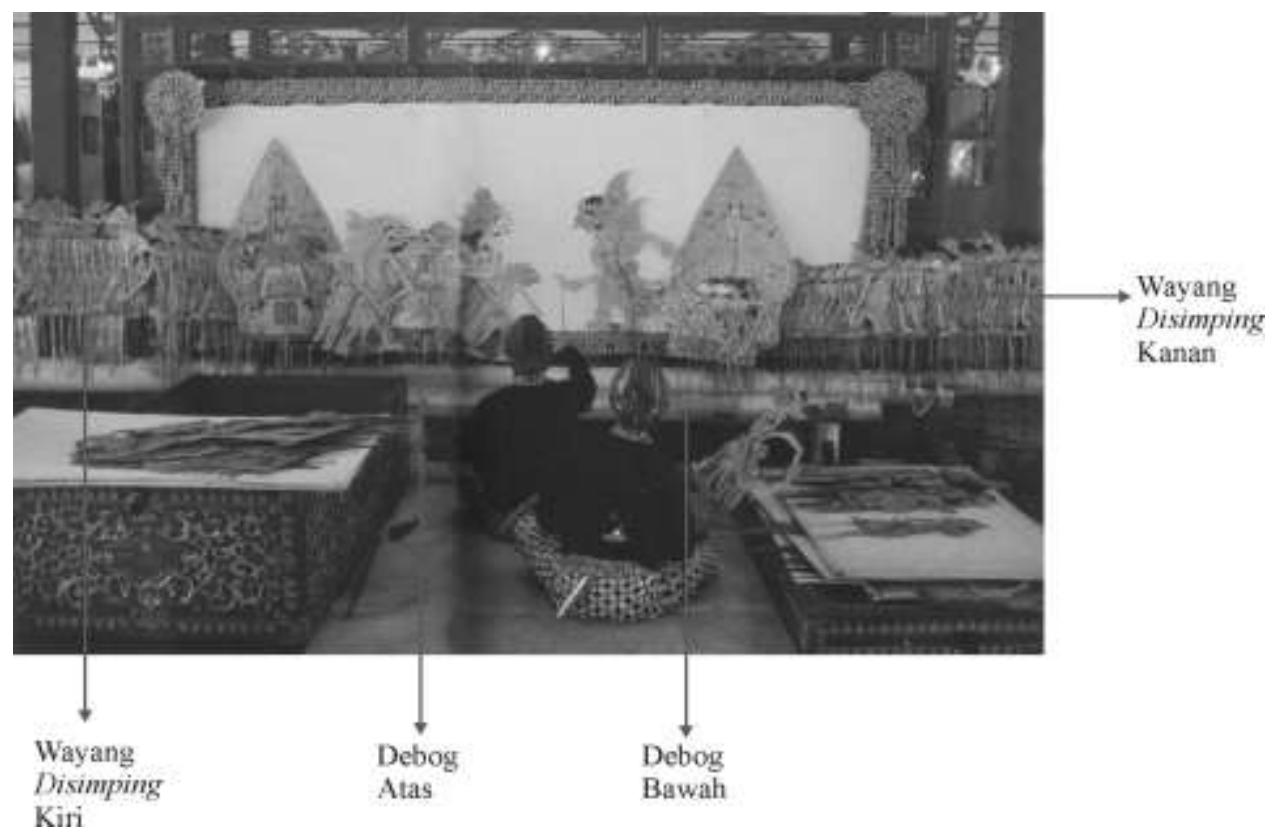

Gambar 2 Panggung wayang kulit, dengan menggunakan debog atas dan debog bawah. Berikut Gunungan dan wayang yang disimping (ditancapkan pada debog/batang pisang). (Gambar repro, Lordly Shades: 54)

Pertunjukan wayang kulit dinikmati dari gerak (sabetan) bayangan pada kelir, yang berasal dari sorot lampu blencong disaat pertunjukan. Pemilihan arah bayangan tersebut karena wayang merupakan pertunjukan bayang-bayang, yakni roh dalam bentuk bayangan yang merupakan lambang watak manusia [5]. Selain itu pergelaran wayang kulit luar, juga diamati dalam bentuk gambargambar dua dimensi dalam bentuk bayangan yang ber "gerak", semacam film. Jadi aspek bayangan yang atraktif dan dramatis. Penulis menggunakan metoda analisis bahasa rupa untuk mengetahui bahasa rupa gerak wayang kulit purwa, khususnya dalam 'membaca" sabetan, untuk mengetahui arti posisi gambar yang dihasilkan dari 'gerak' tersebut.

\footnotetext{
7'Membaca' di sini dimaksudkan dalam arti mengetahui atau memahami arti/maksud gerakan-gerakan tubuh seseorang atau karakter untuk dapat dijelaskan kembali/diceritakan kembali.
} 


\subsection{Teori Bahasa Rupa}

Bahasa rupa $^{8}$ adalah suatu cara yang dipakai untuk berkomunikasi lewat gambar, kerap disebut bahasa gambar. Bahasa gambar tersebut diungkapkan melalui imaji dan tata ungkapan. Imaji mencakup makna yang luas, baik imaji yang ada dalam khayalan maupun imaji yang kasat mata. Oleh karena itu digunakan istilah 'citra' untuk imaji yang bersifat khayalan dan istilah 'wimba' untuk imaji yang kasat mata. Dalam bahasa rupa, wimba (imaji kasat mata) dibedakan atas 'isi wimba' dan 'cara wimba'. 'Isi wimba' ialah objek yang digambar, seperti gambar kerbau masyarakat primitif, kerbau yang digambar itu disebut 'isi wimba'. 'Cara wimba' berarti dengan cara apa objek gambar itu digambar, misalnya, bagaimana kerbau tersebut digambar tampak samping dari kepala sampai kaki, sehingga bahasa tubuhnya bisa dikenali sebagai kerbau, dan cara menggambarkan kerbau tersebut memiliki ciri tampak yang khas [6].

Agar gambar dapat berceritera dikupas dengan isi wimba dan cara wimba agar gambar yang disebut 'tata ungkapan dalam'. Seperti gambar kerbau berkaki enam dalam masyarakat primitif, sebenarnya bukan menceritakan kerbau berkaki enam, tetapi menceritakan kerbau tersebut sedang berlari. Kemudian pada gambar tunggal yang satu disusun dengan gambar tunggal yang berikutnya seolah gambar bisa bercerita, disebut 'tata ungkapan luar'. Bila pada gambar tunggal yang satu berlokasi di luar ruang, sedang gambar tunggal berikutnya berlokasi di dalam ruang, hakikatnya gambar itu telah mengalami peralihan ruang dan waktu.

Primadi secara tegas menyebutkan dua bentuk bahasa rupa pada gambargambar dua dimensi representatif (gambar-gambar yang mewakili dan bisa dikenali benda aslinya). Pertama, 'bahasa rupa modern' menggunakan sistem menggambar yang disebut Naturalis - Perspektif - Momenopname (NPM). Pada bidang kesenirupaan, salah satu pengaruh dari sistem menggambar NPM adalah subjek seakan 'menembak' suatu objek dari satu tempat, ke satu arah tertentu, dan di satu waktu tertentu pula seperti teknik memotret. Hasil

${ }^{8}$ Dalam daftar istilah (disertasi Primadi. 1991) terdapat beberapa definisi dari istilah bahasa rupa, yakni 1). Visual language - Media komunikasi rupa, misalnya gerak, gambar, rambu, dan sebagainya... 2). Bahasa rupa khas - bahasa rupa dari gambar yang diteliti disertasi ini: gambar prasejarah, primitif, anak, Lalitavistara Borobudur, wayang Beber Jaka Kembang Kuning (kemudian disebut oleh Primadi sebagai gambar tradisi. 3). Bahasa rupa media ruparungu dwimatra dinamis - bahasa rupa media ruparungu gerak seperti film, televisi, wayang kulit ... 4). Bahasa rupa media ruparungu dwimatra statis - bahasa rupa media rupa rungu tidak bergerak, seperti wayang beber, slide suara, film strip suara... 5). Bahasa rupa modern - singkatan dari bahasa rupa media rupa rungu dwimatra statis modern... 
gambarnya, merupakan stillpicture (gambar mati, yang 'dipenjarakan' dalam frame/bingkai). Karenanya jenis gambar ini disebut 'gambar diam yang mati tanpa dimensi waktu'. Pada bahasa rupa film/TV merupakan gambar-gambar NPM yang masing-masing gambar dibatasi frame, ${ }^{9}$ dirangkai (berupa 'stop motion') ${ }^{10}$ dengan menggunakan The Grammar of Film/TV Language ${ }^{11}$ untuk menciptakan ruang dan waktu, sehingga memiliki kisah yang dapat diceritakan.

Kedua, sebagaimana diungkapkan oleh Primadi Tabrani, bahwa bahasa rupa masyarakat primitif, yakni gambar-gambar dua dimensi representatif yang menggunakan sistem menggambar Ruang - Waktu - Datar (RWD). Gambar dua dimensi representatif ini merupakan gambar 'aneka tampak'. Meskipun gambar bersifat datar, atau dua dimensi, tetapi mampu merepresentasikan dimensi gerak dan waktu di dalamnya sehingga bisa bercerita, dan disebut 'gambar diam yang hidup'.

Kedua sistem menggambar ini, yakni NPM dan RWD dengan bahasa rupa masing-masing, disebut 'perbendaharaan bahasa rupa dua dimensi gabungan'. Gabungan dari perbendaharaan bahasa rupa NPM dan RWD, disetai 'cara wimba' dan 'tata ungkapan dalam' [7] yang kemudian pada perkembangan selanjutnya menjadi 'perbendaharaan bahasa rupa dua dimensi gabungan lengkap'. Merupakan gabungan dari bahasa rupa NPM dan RWD ditambah aspek 'gerak' yang mencakup gerak 'statis', imaji gerak, cara kembar, lapisan latar, dan semacamnya. Cara menggambar imaji gerak, cara kembar dan lapisan latar, merupakan teknis animasi 'stop motion' diikuti 'cara wimba', 'tata ungkapan dalam', dan 'tata ungkapan luar'.

Dalam kajian ini, teori di atas diadopsi untuk mencoba menelaah gerakan wayang yang direkam melalui video. Dengan demikian gerakan-gerakannya dapat 'dibekukan' (stop motion) dalam bentuk 'frame' yang dapat diamati karakter bahasarupa geraknya.

\footnotetext{
${ }^{9}$ Frame (berasal dari istilah asing) yang dipakai untuk membatasi pandangan pada foto, lukisan, slide, dan negatif film. Panil digunakan untuk membatasi ruang dan waktu pada gambar-gambar relief candi, dan wayang beber. Panil juga digunakan sebagai pembatas pandangan pada gambar-gambar untuk edisi komik.

${ }^{10}$ Stop Motion : merupakan istilah bahasa film untuk editing, yakni pengambilan gambar per-detik, yang umumnya digunakan untuk pembuatan film-film animasi (filmfilm kartun dan film-film bisu model film Charlie Chaplin) yang disusun sedemikian rupa dengan bantuan The grammar of Film/TV Language, sehingga dapat diamati karakter geraknya.

${ }^{11}$ The Grammar of Film/TV Language, merupakan bahasa kamera Film/TV/Video untuk teknik-teknik pengambilan dan merangkai gambar, sehingga secara keseluruhan dapat dipahami ceriteranya.
} 


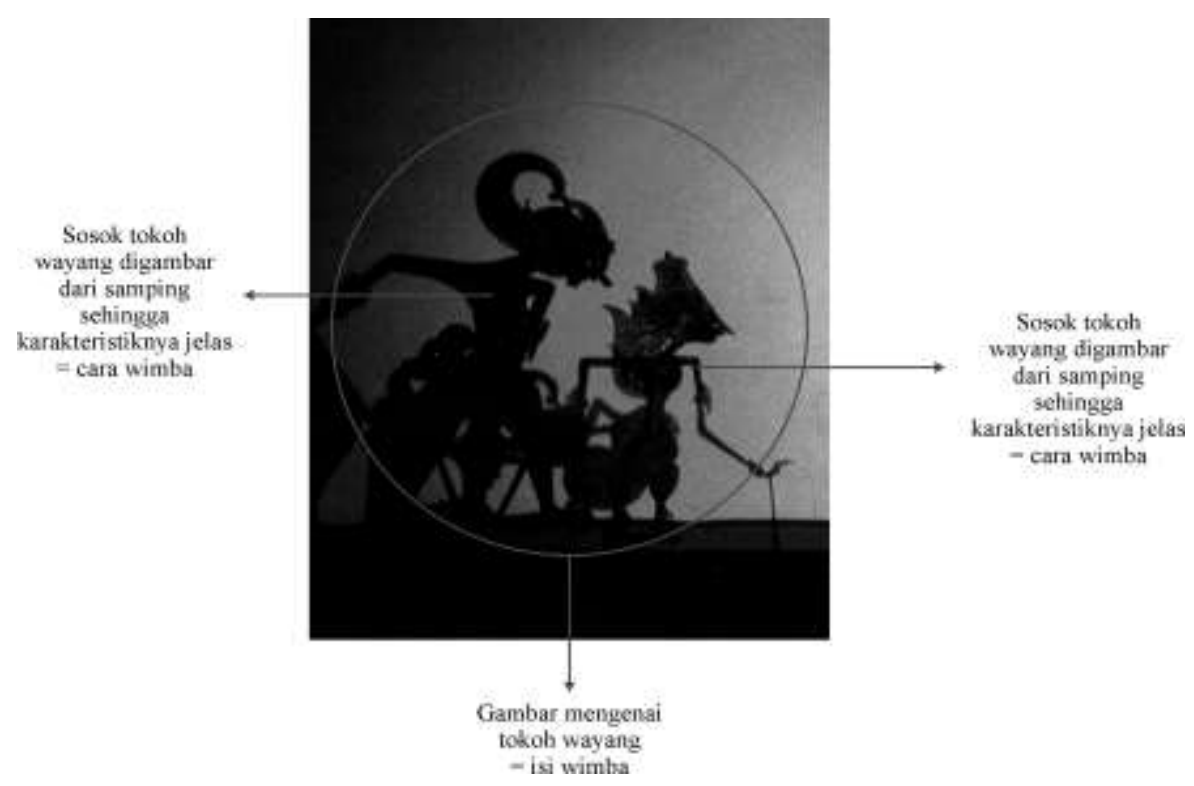

Gambar 3 Contoh dari pengertian istilah 'isi wimba' dan 'cara wimba' pada bahasa rupa wayang kulit dari arah bayangan.

\section{$2 \quad$ Ragam Jenis Gerak Wayang}

Ragam jenis gerak wayang, sangat menentukan tipe karakternya dan kepribadian para tokoh wayangnya. Dikelompokkan dalam tiga bagian penting: gesture (bahasa tubuh), transisi (peralihan satu gerakan ke gerakan berikutnya) dan perang (adegan perang).

\subsection{Bahasa Tubuh/gesture}

Bahasa tubuh yang digunakan, diperlihatkan disetiap adegan adalah bahasa tubuh formal. Posisi standar yang biasa digunakan dalang, yaitu sosok wayang dalam posisi diam dengan gapit (batang kendali tubuh/utama boneka wayang) ditancapkan pada debog (batang pohon pisang yang dibaringkan di dasar layar). Pada posisi ini yang bergerak hanya lengan yang digerakkan melalui tuding (batang kendali lengan pada boneka wayang) oleh dalang. Pada gerakan tersebut, dalam kondisi diam ditancapkan di debog, terdapat beberapa jenis tancap, yakni: tancep 0 (tancap di simping), tancap jejer (tancap pada awal adegan), dan tancap adegan. Pada tancap adegan ini, gerakan-gerakan lengan di saat diam (tancap pada debog) juga menentukan tipe karakter dari tokoh wayang. Pada posisi angapurancang hingga mathentheng $C$, merupakan tancep jejer, sedangkan posisi malang kadhak A dan malang kadhak B merupakan tancep adegan. Malangkerik A, hingga gerakan makidhupuh dan kingkin, 
merupakan bentuk sabetan. Lihat pada contoh gambar-gambar posisi standar dalam keadaan diam (lihat pada Gambar 4: ragam posisi diam ditancapkan)

Posisi lengan angapurancang, merupakan posisi lengan pada tipe karakter yang lebih tenang. Posisi tuding dan gapit berada pada satu tangan genggaman dalang. Biasanya bila dimainkan, gapit berada ditancapkan pada batang pisang, dan tuding (berupa 2 tangkai kiri dan kanan) dimainkan secara bergantian untuk menunjukkan karakter tokohnya atau sekaligus bersama gapit ditancapkan pada batang pisang (debog) sebagai panggung.

Posisi lengan anjujur merupakan posisi lengan yang serupa dengan angapurancang tetapi posisi lengan ini, lebih bebas dari posisi angapurancang. Pada posisi lengan anjujur berada lurus kebawah, pada posisi anjujur ke dua tangkai tuding tidak dalam posisi di tancapkan. Posisi dua tangkai tuding lebih bebas digerakkan oleh dalang untuk menunjukkan karakter tokohnya.

Posisi mathentheng A (Lihat Gambar 4) merupakan posisi pada salah satu lengan berada di lekuk pinggul, dengan gapit ditancapkan pada debog. Bahasa tubuh ini digunakan oleh semua tipe karakter tokoh wayang, baik tokoh berwatak halus, berwatak gagah atau tokoh berwatak kasar. Pada kasus tertentu, lengan yang di depan diletakkan di pinggul (mathentheng B) Variasi dari posisiposisi ini biasanya digunakan untuk yang memiliki karakter keras kepala atau karakter-karakter yang sulit diajak kompromi. Untuk versi yang lain (mathentheng $\mathrm{C}$ ), merupakan gerakan dasar untuk memulai berjalan atau bersiap-siap untuk terbang.

Posisi malang kadhak (A dan B, Gambar 4) merupakan posisi dasar yang diperlukan untuk gerakan berlari, berjalan, terbang atau perkelahian.

Posisi malang kerik (Gambar 4) merupakan bahasa tubuh untuk menyatakan sikap melawan, atau posisi tangan dalam keadaan terbang (malang kerik A) sedangkan variasi yang lain (malang kerik B) kedua tangan diletakkan di pinggang, merupakan sikap bahasa tubuh untuk bersiap-siap menyerang. Pada posisi malang kerik ini, dalang menggunakan tuding untuk menggerakkan lengan-lengan tersebut dengan satu tangan, dan menggenggam gapit pada tangan yang lain. Posisi ini juga merupakan posisi untuk siap berkelahi, berjalan atau terbang dalam gerakan yang lebih cepat.

Posisi makidhupuh (Gambar 4) merupakan bahasa tubuh yang unik untuk posisi wayang kulit duduk bersimpuh atau duduk bersimpuh sambil berjalan. Posisi siku depan dan siku belakang berada segaris dengan dasar panggung, tuding dan gapit berada dalam tangan yang terpisah dari dalang. Seperti tuding digerakkan di satu tangan dan gapit berada di genggaman tangan yang lain. Terutama bila 
tokoh tersebut dalam posisi bergerak (bersimpuh sambil berjalan) atau posisi makidhupuh sambil menyembah.
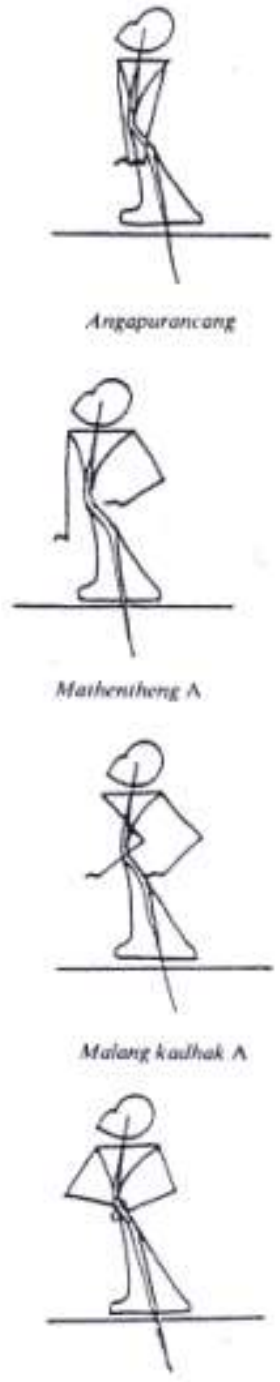

Molangkerik B

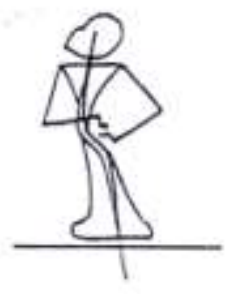

Mathentheng B

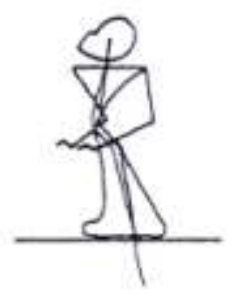

Malang hedhat B

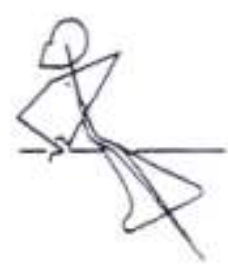

Makidhupuh
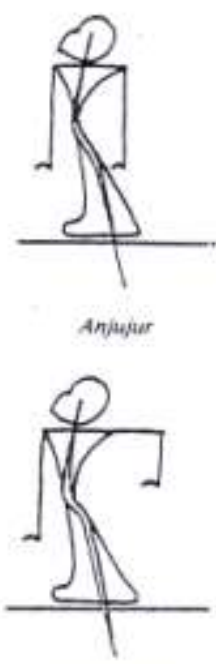

Mathentherig C

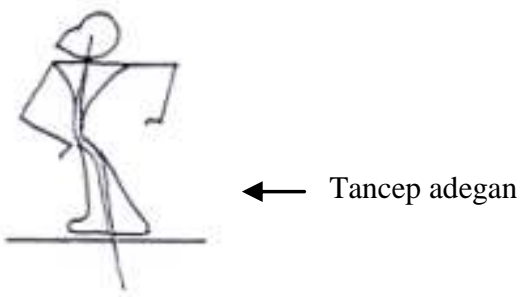

Malang kerik A

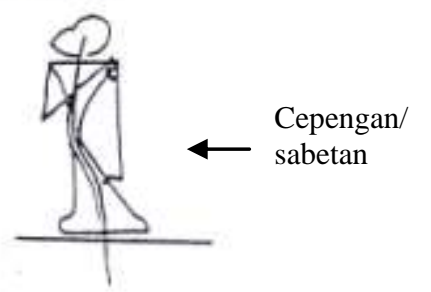

Kingioin

Gambar 4 Ragam posisi diam ditancapkan (Roger Long. 1979). 
Posisi kingkin (Gambar 4) merupakan bahasa tubuh yang menyampaikan pesan bahwa karakter tertentu sedang dalam keadaan gelisah, kebingungan atau kesusahan. Tangan diletakkan dibahu atau kadang kala pada variasi tertentu, posisi tangan diletakkan di atas perut; sebagai contoh, tokoh tersebut kehilangan saudaranya di waktu perang, atau terbunuh pada perkelahian yang seru.

Bahasa tubuh formal pada suatu karakter untuk menunjukkan rasa hormat dan kesetiaan pada seorang raja, biasa disebut sembah. Pada umumnya bahasa tubuh sembah ini untuk segala macam karakter wayang, dengan mengarahkan tangkuban tangan ke hidung atau ke dahi. Ada lima macam gerak sembah yang biasanya digunakan untuk membina hubungan relasi terhadap raja, teman dan keluarga, yakni sembah ratu, sembah karna, sembah jaya, sembah suwunan, sembah biasa. Secara umum, yang sering digunakan adalah sembah ratu dan sembah karna, karena ke dua gaya sembah ini sering digunakan dalang pada pentas pagelarannya.

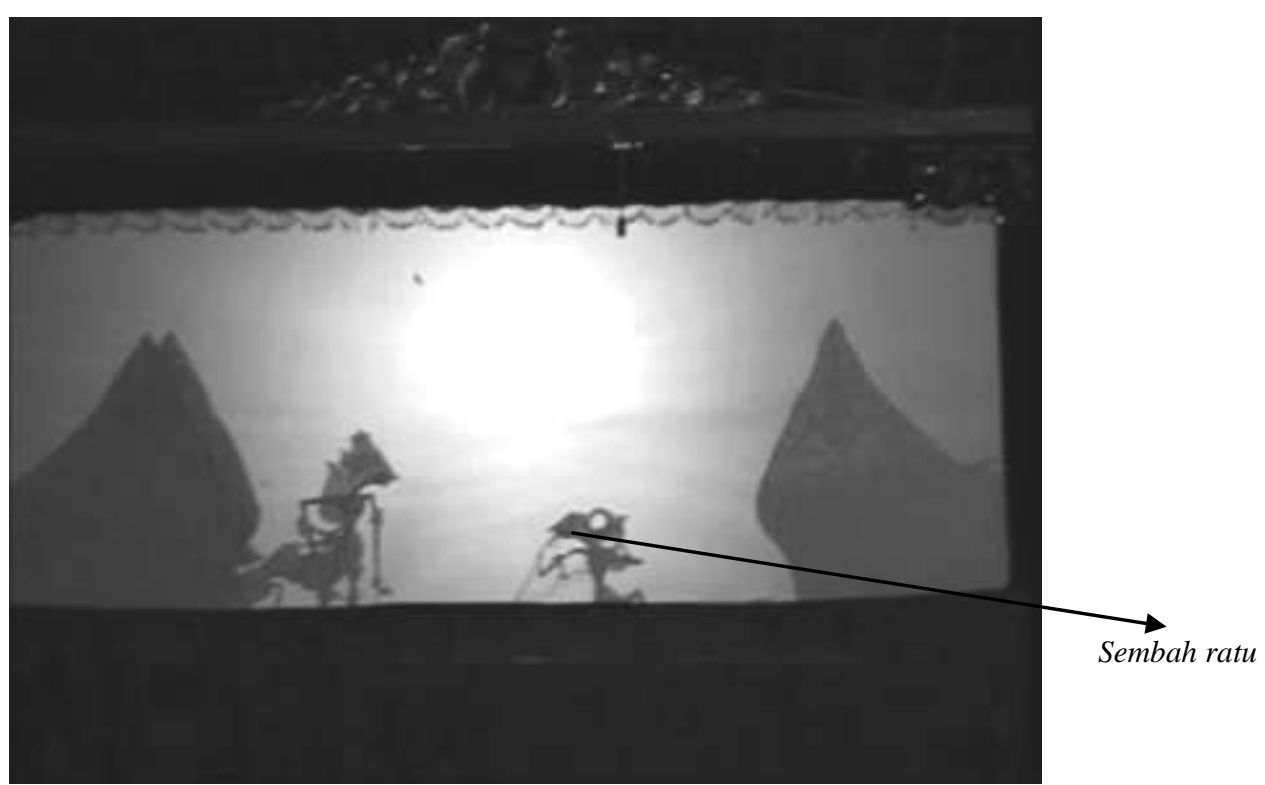

Gambar 5 Memperlihatkan bahasa tubuh sembah ratu, terhadap raja yang diposisikan sebelah kiri kelir. Disebelah kanan kelir yang melakukan sembah, yang baru datang, keluarga yang lebih muda, atau kedudukan lebih rendah. (Video/sequence ke 5 dari transkrip Parta Krama)

Sembah ratu (Gambar 5) adalah gerakan sembah yang ditujukan kepada raja, dengan posisi bersimpuh, tangan ditangkupkan kearah hidung atau dahi, merupakan karakter dan sekaligus menunjukkan kepribadian untuk rasa hormat kepada raja. Bahasa tubuh ini lazim digunakan keluarga yang lebih muda 
kedudukan dan usia dari pada raja, para bawahan, atau tamu yang lebih muda usianya.

Bahasa tubuh sembah karna (Gambar 6) dilakukan oleh tamu raja yang lebih tua, atau sesama raja. Hal itu biasa dilakukan oleh saudara tua Kresna, Prabu Baladewa, atau beberapa karakter dari keluarga Kurawa, salah satunya adalah adipati Karna. Posisi tubuh tetap berdiri, tidak perlu duduk bersimpuh, satu tangan digerakkan ke atas, dan tangan yang lain dalam posisi lengan di pinggang atau lurus ke bawah.

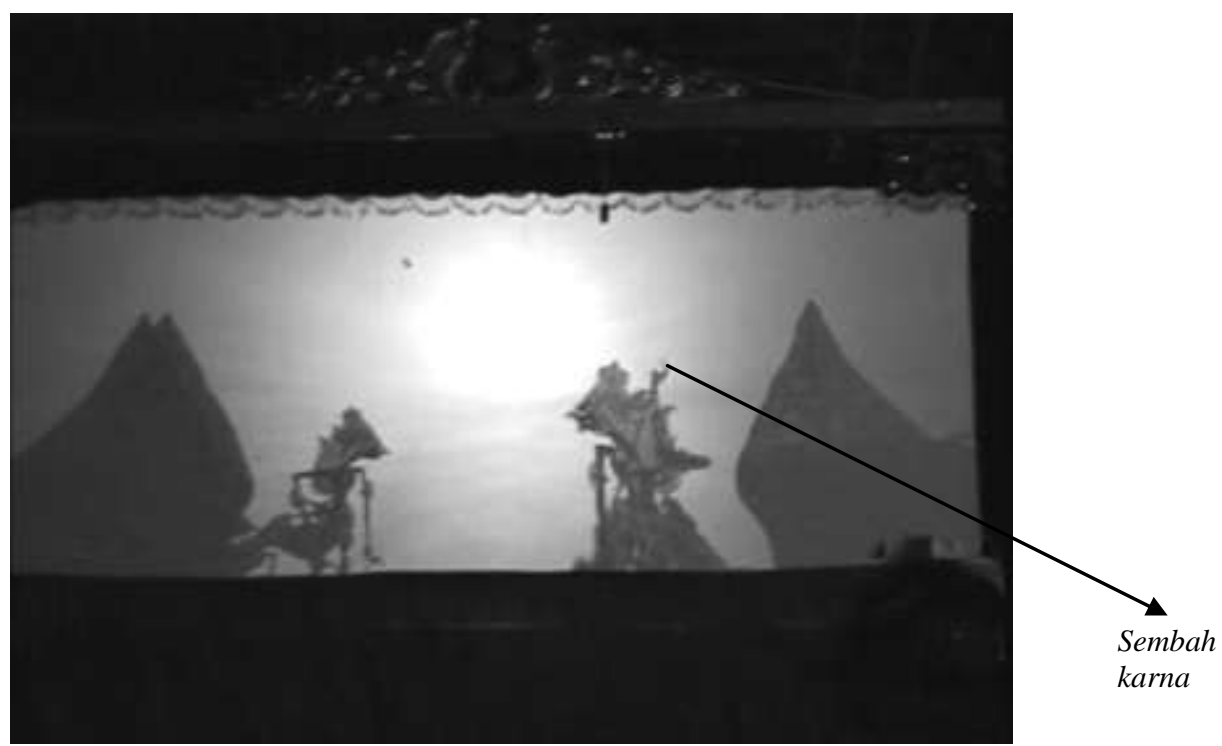

Gambar 6 Bahasa tubuh dari sembah karna, yang digunakan oleh tamu dari raja. Posisi tamu sebelah kanan kelir, tapi karena tamunya adalah sesama raja dan saudara tua, Maka cukup dengan menggunakan sembah karna. (Video.sequence. ke 6 transkripsi Parta Krama).

Ada bentuk salam yang lain selain sembah karna untuk para raja, yakni salam saling berjabat tangan (Gambar 7). Untuk salam yang saling berjabat tangan, hanya digunakan oleh sedikit karakter dari para tokoh wayang. Meskipun gerak wayang kulit menggunakan cara budaya tradisional, tapi semangatnya merupakan semangat sepanjang jaman. 


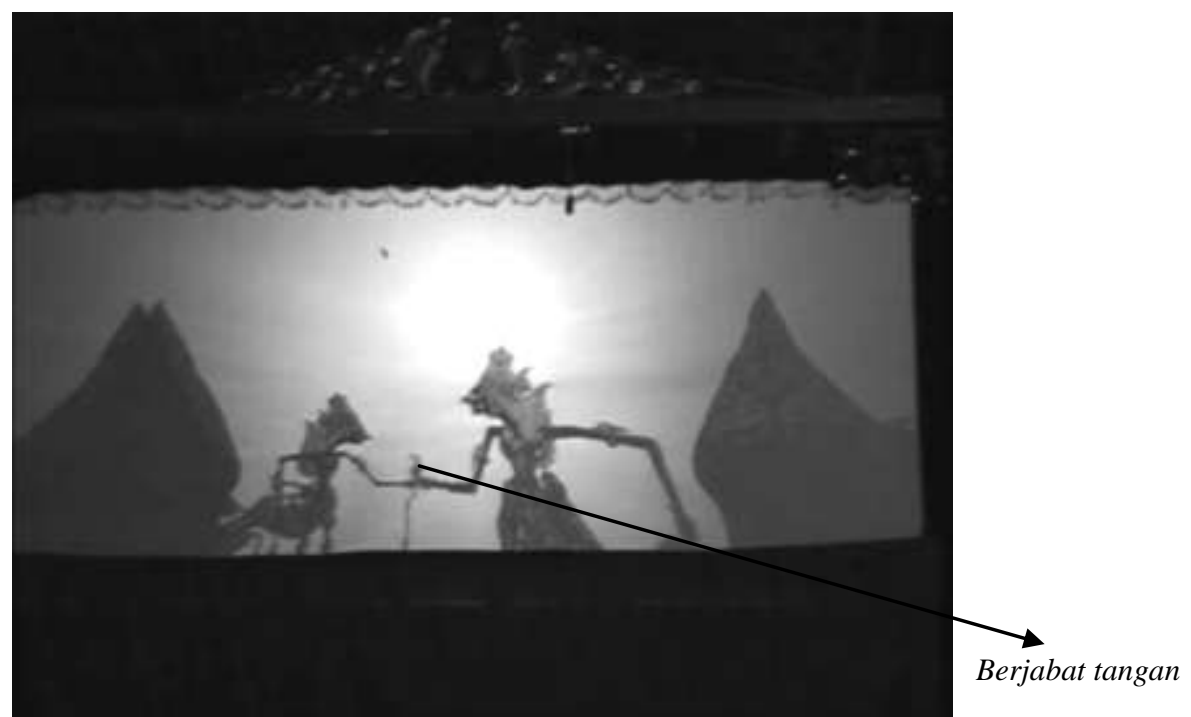

Gambar 7 Bahasa tubuh yang lain selain sembah karna, yakni berjabat tangan. Hanya sedikit para tokoh yang menggunakan bahasa tubuh untuk memberikan salam dengan cara berjabat tangan. Karena hanya para raja yang menggunakan bahasa tubuh untuk salam seperti ini. (Video, sequence ke 6, transkrip Parta Krama).

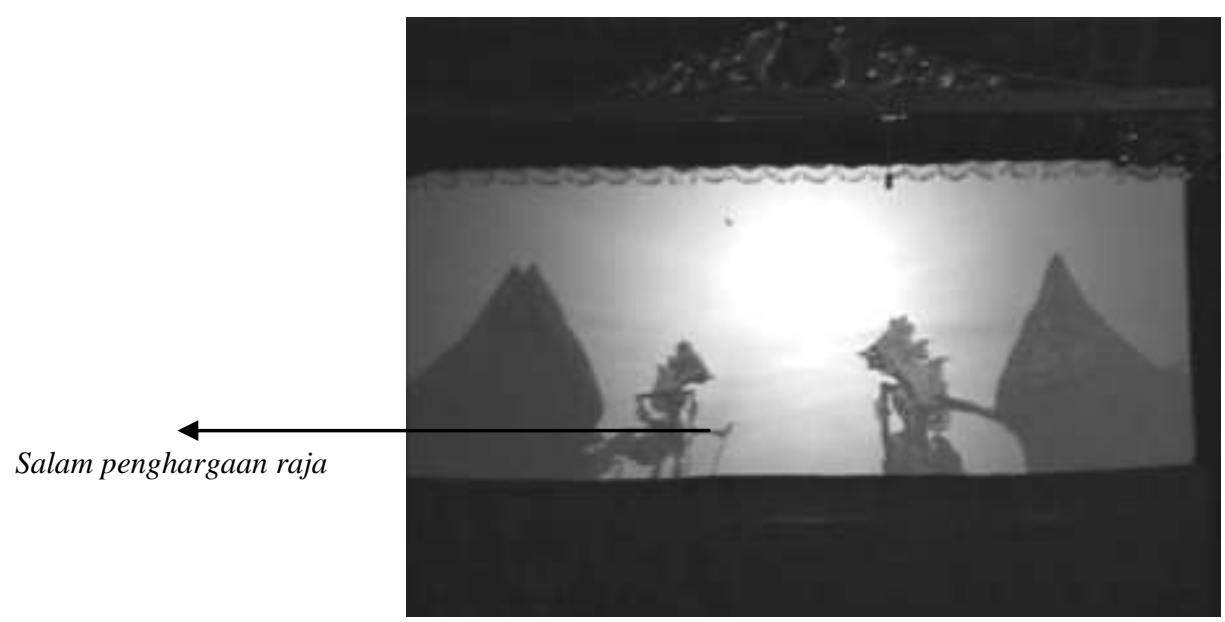

Gambar 8 Bahasa tubuh dari salam penghargaan raja terhadap tamunya. Salam ini merupakan gerakan tubuh yang biasa terdapat pada masyarakat Jawa, bila membalas salam dari teman, kerabat dan keluarganya. (Video, sequence ke 6, transkrip Parta Krama) 
Biasanya sang raja merespons dengan bahasa tubuh yang bervariasi dengan hanya menggerakkan tangan kedepan beberapa sentimeter dengan menutup jarijari tangannya, kecuali ibu jari yang menonjol (Gambar 8). Bahasa tubuh ini merupakan bahasa tubuh yang biasa digunakan dalam adat isitiadat budaya Jawa. Pada wayang kulit, memang tidak terlihat ibu jari seperti pada umumnya ibu jari manusia, tetapi gerakan dari bahasa tubuh ini merupakan gerakan yang biasa digunakan masyarakat Jawa untuk memberi salam kepada sesamanya.

Ketika terjadi dialog antara tokoh satu dengan yang lain, terdapat beberapa bahasa tubuh yang biasa digunakan para tokohnya berdasarkan karakter. Gerakan baku umumnya, dengan menggerakkan tangan ke depan, hanya perbedaannya terletak pada posisi lengan yang digerakkannya. Untuk menggerakkan posisi lengan tersebut, disertai cara berbicara para tokohnya. Bila berbicara cepat, tangan dan lenganpun bergerak dengan cepat. Bila berbicara lambat atau berbicara lembut, gerakan tangan dan lengan juga cenderung melambat. Untuk gerak lengan yang tinggi atau cepat, begitu pula sebaliknya, menunjukkan tipe kepribadian para tokohnya dan juga situasi yang dihadapi. Untuk para tokoh yang berkepribadian lembut, hanya menggerakkan tangannya, sejauh tiga atau empat centimeter dari tubuhnya (Gambar 8). Tetapi untuk karakter yang lebih agresif, dapat mengangkat tangannya setinggi tubuhnya dan dengan gerakan cepat, dan kadangkala pergelangan tanganpun ikut bergerak cepat (Gambar 9)

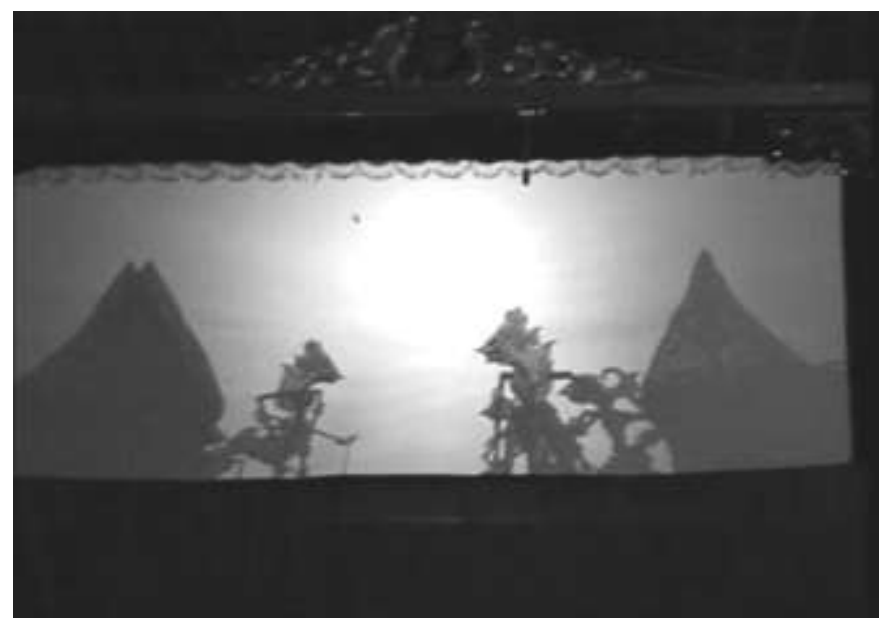

Gambar 9 Bila terjadi dialog, bahasa tubuh untuk tokoh yang halus, hanya menggerakkan tangan seperlunya. Pada foto ini sang raja Kresna (kiri kelir) menggerakkan tangan sedikit ketika berdialog dengan tetamunya. (Video, sequence ke 7, transkripsi Parta Krama) 


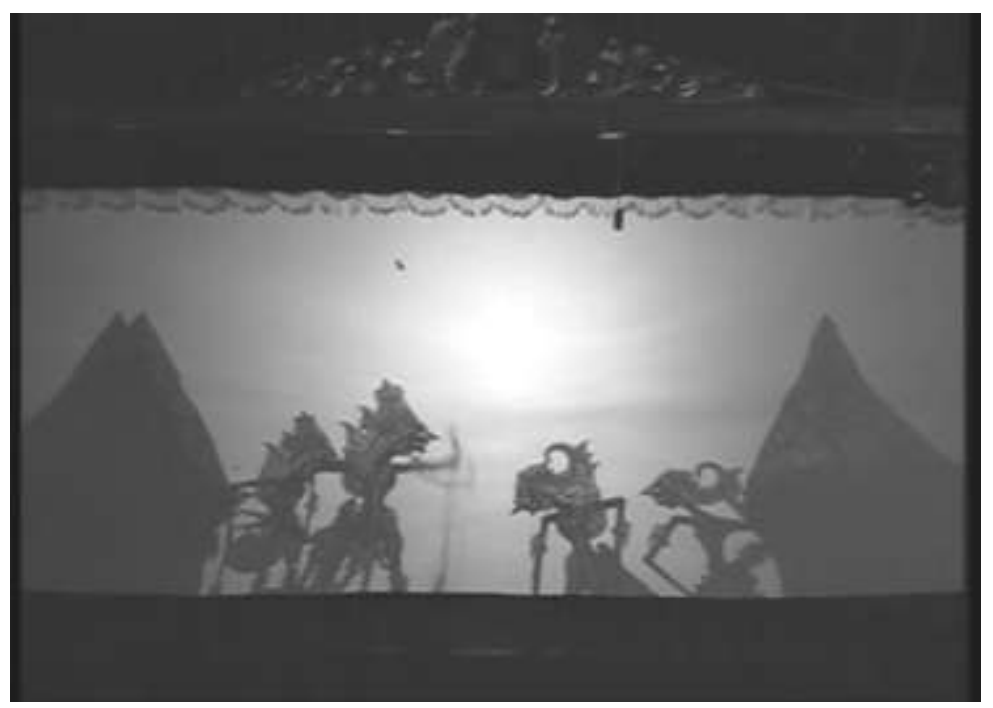

Gambar 10 Menggambarkan situasi kemarahan yang terjadi pada Prabu Baladewa (ke dua dari kiri kelir) terhadap Gathotkaca (ke dua dari kanan kelir) yang datang bertamu. (Video, sequence ke 10, transkripsi Parta Krama).

Bahasa tubuh karakter agresif, pada adegan tertentu bisa menimbulkan perang. Bahasa tubuh ini terkesan dinamis dan keras sekaligus kasar, dan biasanya disertai dengan bentakan-bentakan keras atau disertai pula dengan goncangan pada wajah atau tubuhnya. Terlebih pada para raksasa, bahasa tubuh mereka lebih cepat, keras dan lebih kasar.

\subsection{Gerakan-Gerakan Transisi}

Sosok wayang bergerak di layar dengan tempo yang lama, menunjukkan perpindahan dari satu ruang ke ruang yang lain atau dari suatu tempat ke tempat yang lain dari suatu negara atau suatu kerajaan atau suatu peristiwa perang. Bila seorang tokoh keluar atau masuk dari/ke layar, terdapat kelanjutan gerak dari suatu ruang, misal dari kiri layar atau kanan layar menuju ke layar berikut dengan tanda 'jeda' sebelum melakukan aktivitas lagi.

Jenis gerak dari satu ruang ke ruang yang lain biasanya menunjukkan sang tokoh sedang berjalan, berlari, terbang dan naik kendaraan (pada adegan 'Parta Krama' tidak terdapat adegan tokoh naik kendaraan, misalnya berkuda atau berkereta, sehingga tidak dapat diberikan contoh dari adegan tersebut). Kemudian kesaktian tokoh dapat diketahui dari bagaimana sang tokoh bergerak, bersikap dan bertingkah-laku. Kemudian pada saat adegan perang, terdapat adegan 'jungkir-balik' yang dilakukan pada saat berperang atau perkelahian yang dilakukan secara berkelompok atau satu lawan satu. 


\subsection{Berjalan}

Terdapat beberapa gaya berjalan dari wayang kulit gaya Yogyakarta, seperti pada contoh-contoh gambar di bawah ini. Ke dua gambar di bawah merupakan contoh dari gaya berjalan halus, yang biasa dilakukan oleh tokoh puteri atau satria berkarakter halus. Gambar di bawah merupakan cara berjalan dua putri di suatu kerajaan (Gambar 11 dan Gambar 12).

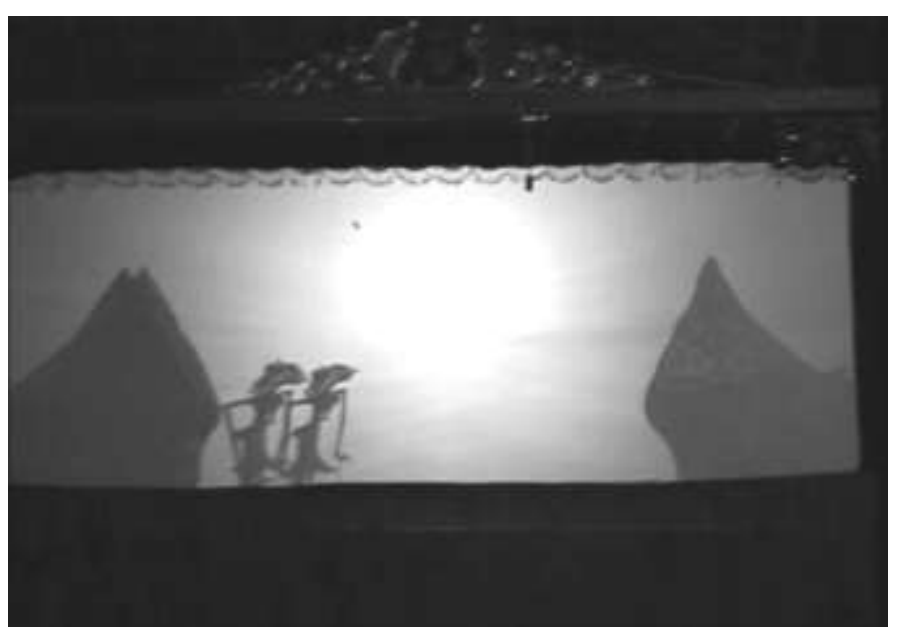

Gambar 11 Kedua putri berjalan halus dari posisi kiri layar. Merupakan contoh dari gaya berjalan halus (Video, sequence ke 3, transkripsi Parta Krama).

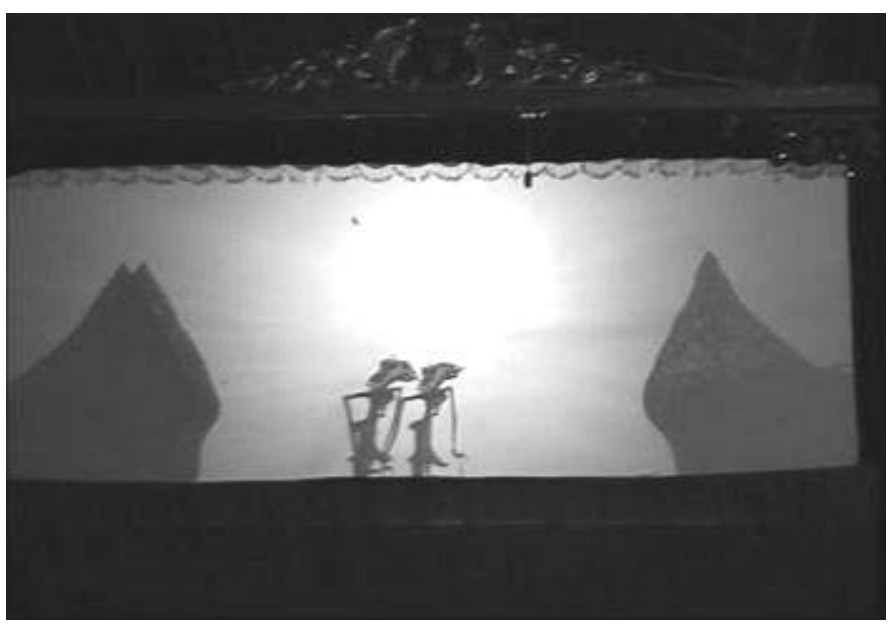

Gambar 12 Contoh cara berjalan halus, lengan dan tangan tidak banyak bergerak. (Video, sequence ke 3, transkripsi Parta Krama) 
Contoh gaya berjalan yang lebih bebas, yang biasanya dilakukan pada para tokoh satria yang lebih gagah. Gerakan yang lebih cepat daripada gerakan gaya berjalan halus dengan jarak langkah antara 5 sampai 10 centimeter (Gambar13)

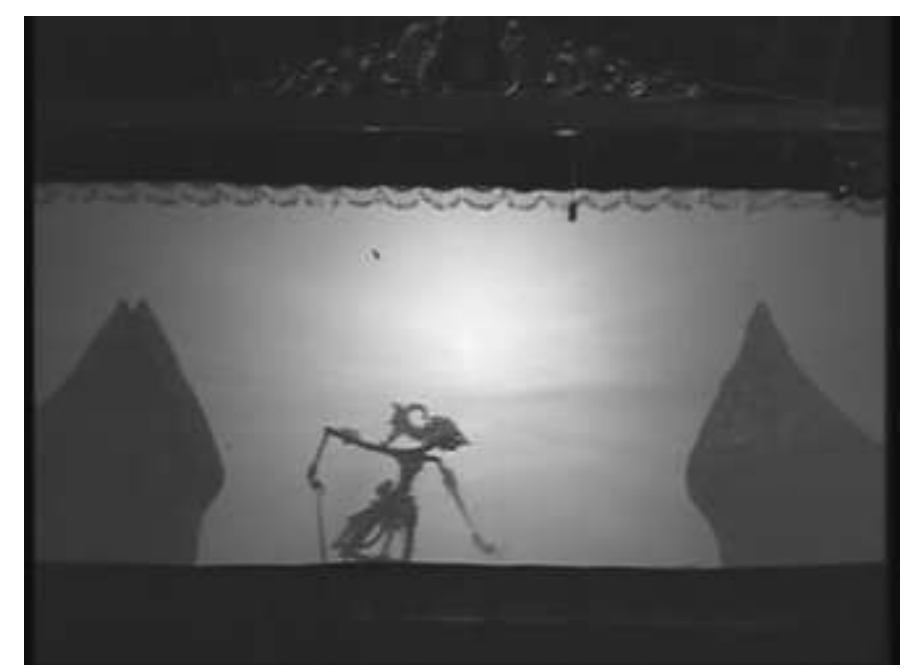

Gambar 13 Contoh cara berjalan yang lebih bebas. Biasa dilakukan oleh tokoh yang berkarakter gagah.Muncul dari kiri kelir (Video, sequence ke 20, transkripsi Parta Krama)

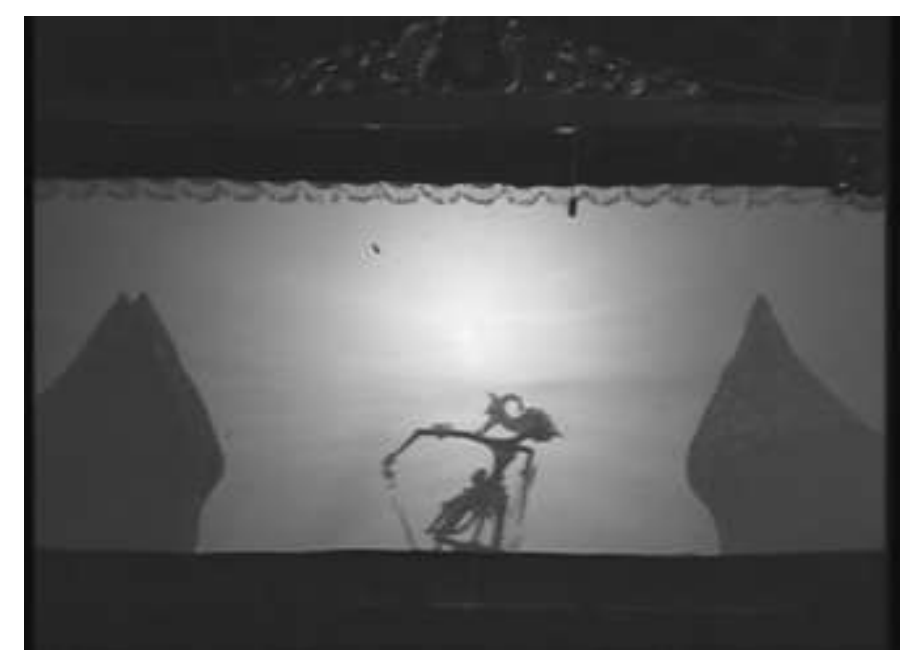

Gambar 14 Gaya berjalan ini, merupakan bahasa tubuh berjalan yang lebih aktif. (Video, sequence ke 20, transkripsi Parta Krama) 
Untuk gerakan bahasa tubuh dengan gaya berjalan yang lebih kasar, biasanya lebih sering dipakai oleh para raksasa atau sering dipakai oleh keluarga Kurawa, misalnya patih Sengkuni.

\subsection{Gerak yang Pelan Sekali dengan Posisi Jongkok}

Gerak yang pelan sekali dengan posisi jongkok dalam istilah wayang kulit disebut lampahan dhodhok. Posisi ini dilakukan bila berhadapan sekaligus berjalan di depan raja. Posisi ini menggunakan ke dua tangan untuk bergerak dengan lutut segaris dengan lantai panggung. Dalang memainkan dengan cara badan wayang bergerak ke depan terlebih dahulu, kemudian kedua tangan, lalu bagian kaki (Gambar 15).

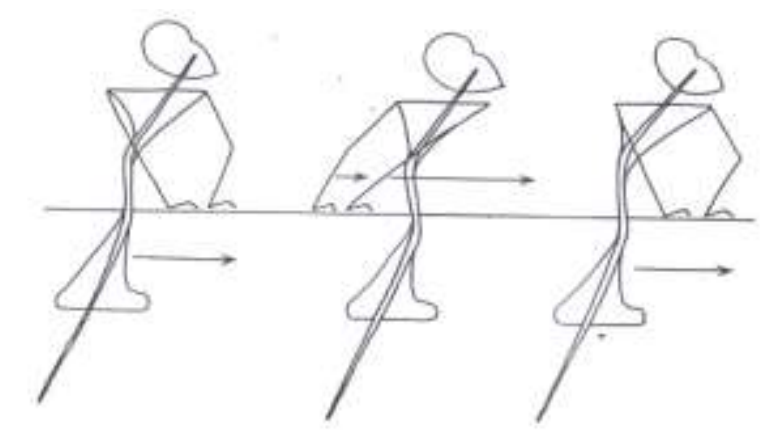

Gambar 15 Posisi lampah dhodhok dengan menggunakan 2 tangan. (Roger Long. 1979)

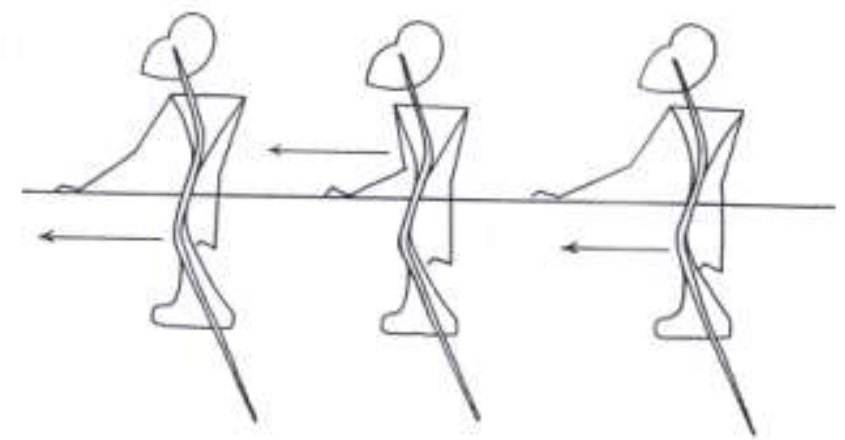

Gambar 16 Variasi lampah dhodhok dengan menggunakan satu tangan. (Roger Long. 1979) ${ }^{\mathrm{i}}$

Berjalan jongkok dengan satu tangan juga dilakukan oleh beberapa tokoh yang lain sebagai variasi. Berjalan jongkok dengan satu tangan dipakai diakhir perkelahian atau perang, sebagai pernyataan ampun dari pihak yang kalah 
kepada pihak yang menang, dan juga sebagai variasi pula dari berjalan secara normal. Dalang memainkannya dengan badan dan tangan yang digerakkan terlebih dahulu, kemudian bagian kaki wayang yang lain. (Gambar 16)

\subsection{Menari}

Sebagian besar tarian dasar dalam wayang kulit merupakan gerakan-gerakan yang berlebihan, yang dalam gerakan itu disesuaikan dengan musik gamelan terutama ketukan nya. Gerakan-gerakan tari ini bisa merupakan gerakan yang berputar-putar, atau gerakan-gerakan yang menyentak naik turun dan semuanya itu dilakukan di satu ruang. Gerakan-gerakan ini juga menunjukkan gerakan melawak, seperti tarian Cangik (nama salah seorang punakawan), pada jejer satu adegan Limbukan, lakon Parta Krama.

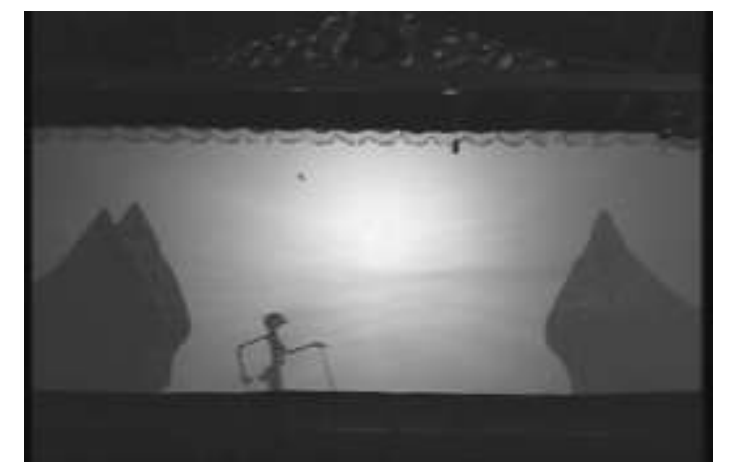

Gambar 17 Adegan Cangik Menari. Transkripsi Lakon Parta Krama Sequence ke 26.

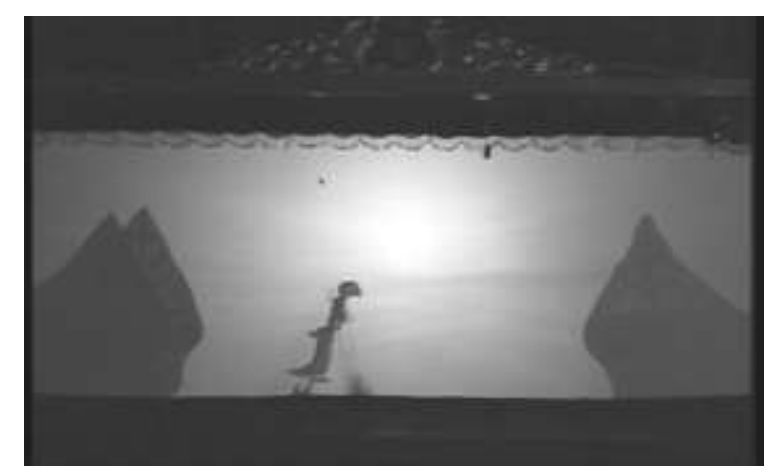

Gambar 18 Adegan Cangik Menari. Transkripsi Lakon Parta Krama Sequence ke 26. 


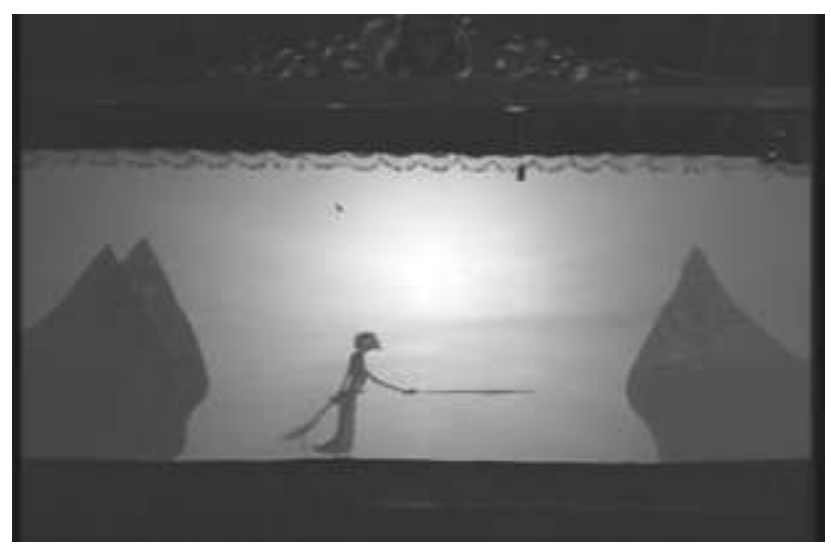

Gambar 19 Adegan Cangik menari. Transkripsi Lakon Parta Krama Sequence ke 26.

\subsection{Terbang}

Karakter-karakter visual wayang tertentu dicirikan mempunyai kemampuan untuk terbang dengan menghentakkan kaki bisa langsung terbang ke udara. Posisi tangan dalam keadaan malang kerik A (Gambar 4). Rata-rata ketinggian jarak terbang, yang paling tinggi kurang lebih tujuh puluh lima sentimeter dari atas tanah/ dasar panggung. Meskipun tidak menggunakan sayap, tetapi dengan hentakan kaki yang kuat, mereka dapat terbang tinggi di angkasa. Karakter dari tokoh yang paling terkenal dengan kemampuan terbangnya yang luar biasa adalah sosok Gathotkaca.

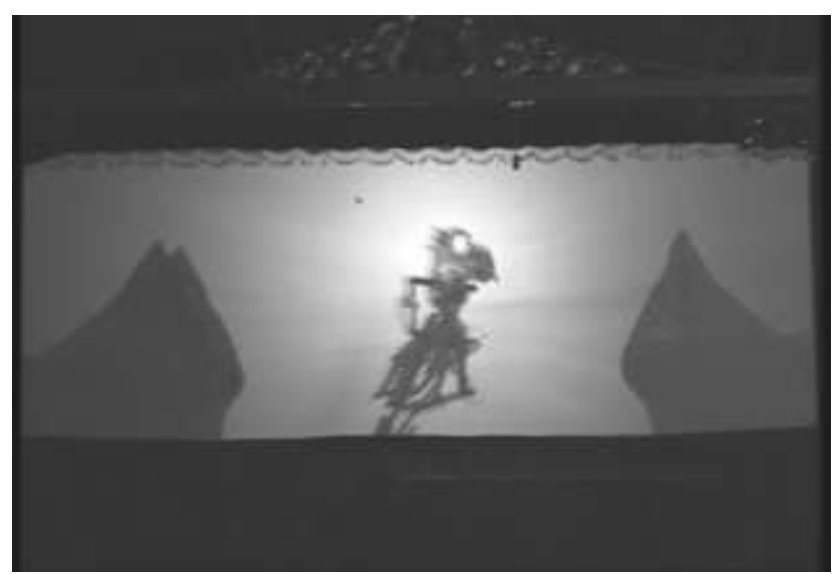

Gambar 20 Gathotkaca sedang terbang rendah disaat perang dengan Kurawa. Sequence 34 transkripsi Parta Krama. 


\subsection{Perang}

Pada skenario yang dibuat oleh sekolah pedhalangan Habirandha, terdapat tiga puluh dua gerakan perang gaya wayang kulit Yogyakarta. Gerakan-gerakan tubuh itu meliputi, gerakan sergapan/terjangan, lemparan, tikaman, pembunuhan dan gerakan-gerakan jatuh, yang biasa terjadi pada peristiwa perang. Gerakan-gerakan dikelompokkan dalam pengelompokan umum, yakni gerakan menyerang, gerakan menghindar dan gerakan jatuh, dan ini berlaku untuk semua karakter atau semua individu.

\subsection{Penyerangan}

Setelah terjadi konfrontasi verbal antara pihak lawan biasanya diikuti dengan gerakan penyerangan dalam suatu perang. Beberapa tipe gerakan menahan dan menyerang dengan menggunakan genggaman tangan (nyepeng) seperti melakukan penyerangan dengan menahan kepala (sirah)(Gambar 22), tangan atau badan (jaya), setelah menahan biasanya mereka menyerang dengan memutar-mutarkannya. Ada gerakan yang digunakan untuk menahan serangan dengan menahan tubuh lawan yang disebut nyikep (Gambar 21). Bahasa tubuh ini, biasanya digunakan untuk menahan gerakan lawan yang lebih agresif. Gerakan-gerakan menahan ini merupakan suatu upaya untuk menahan atau menghentikan gerakan lawan

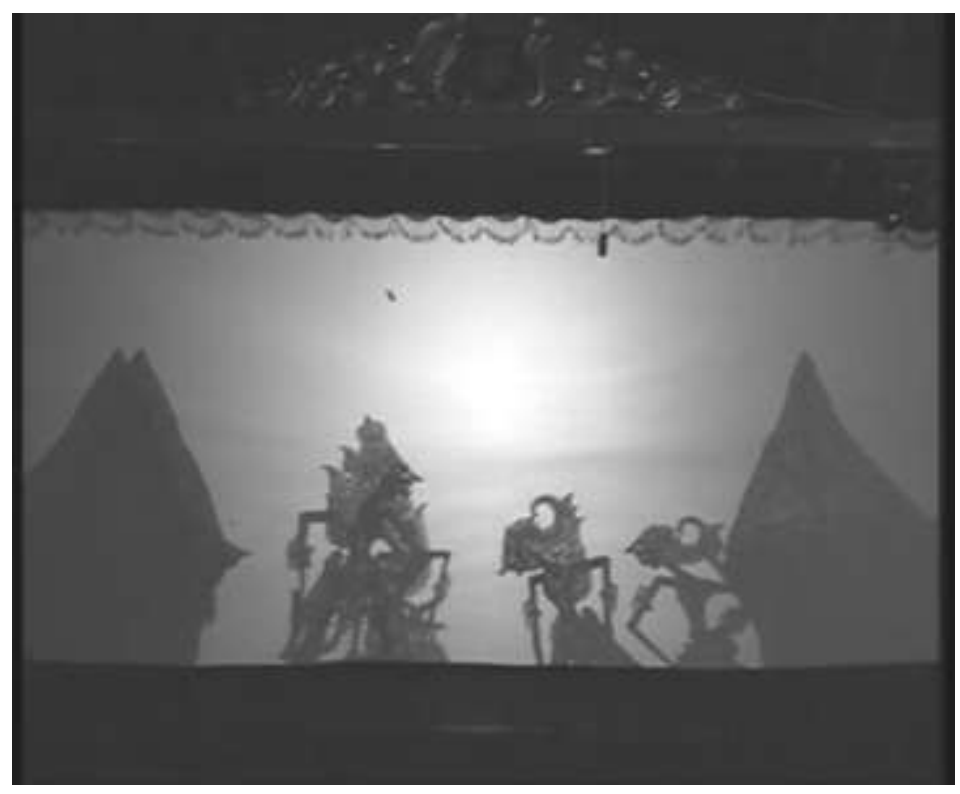

Gambar 21 Gerakan nyikep sequence 11, transkripsi Parta Krama. 


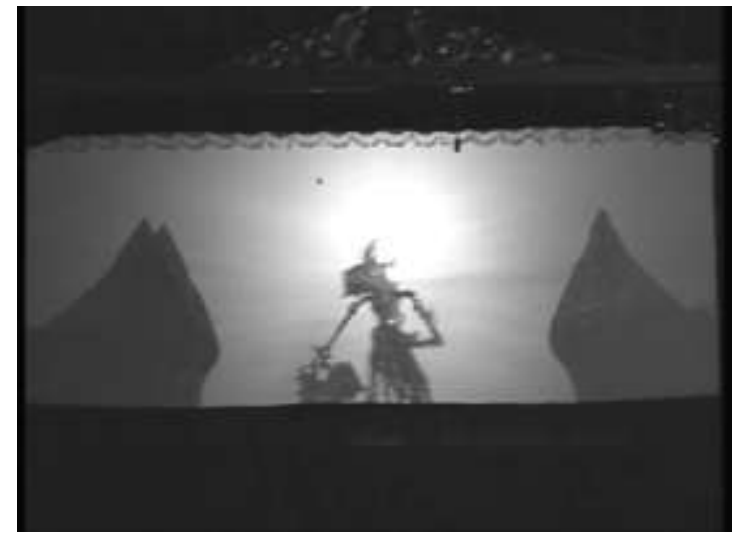

Gambar 22 Gerakan menahan kepala (sirah).

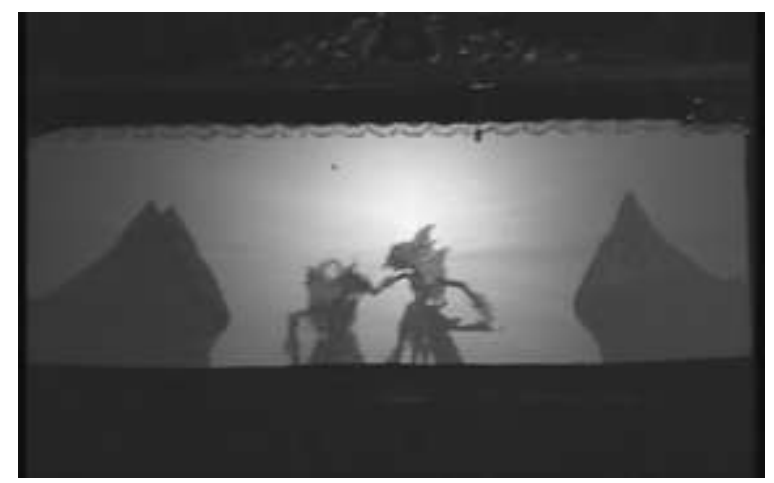

Gambar 23 Gerakan njunjung/ngangkat dalam perang ampyak, sequence 43, transkripsi Parta Krama (A).

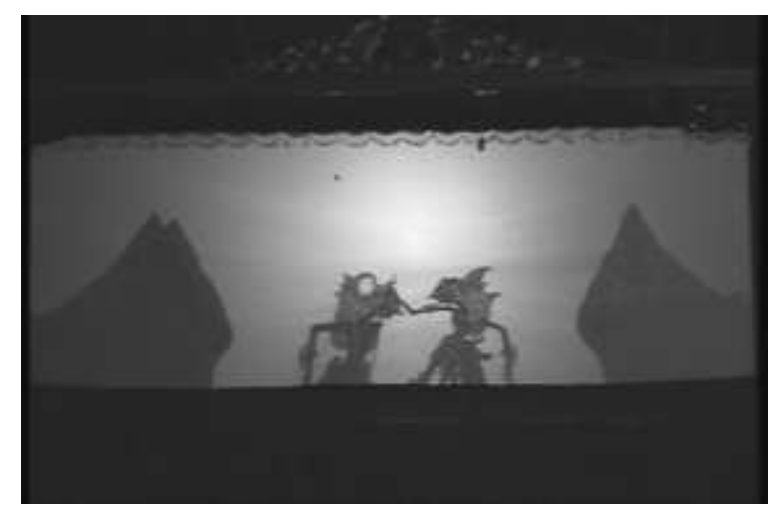

Gambar 24 Gerakan njunjung/ngangkat dalam perang ampyak, sequence 43, transkripsi Parta Krama (B). 
Beberapa karakter memiliki kemampuan untuk mengangkat lawan ke udara disebut njunjung (Gambar 23 dan Gambar 24), setelah itu di jatuhkan dengan keras ke tanah disebut mbanting (Gambar 25), dan kemudian dilempar, gerakan melempar disebut mbucal (Gambar 26).

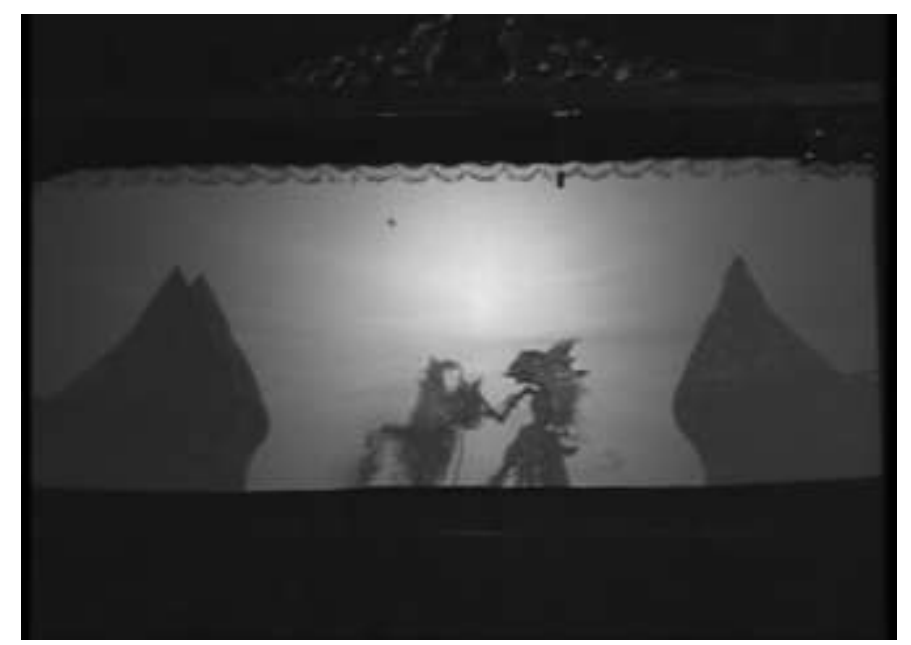

Gambar 25 Gerakan mbanting dalam perang ampyak, sequence 43, transkripsi Parta Krama.

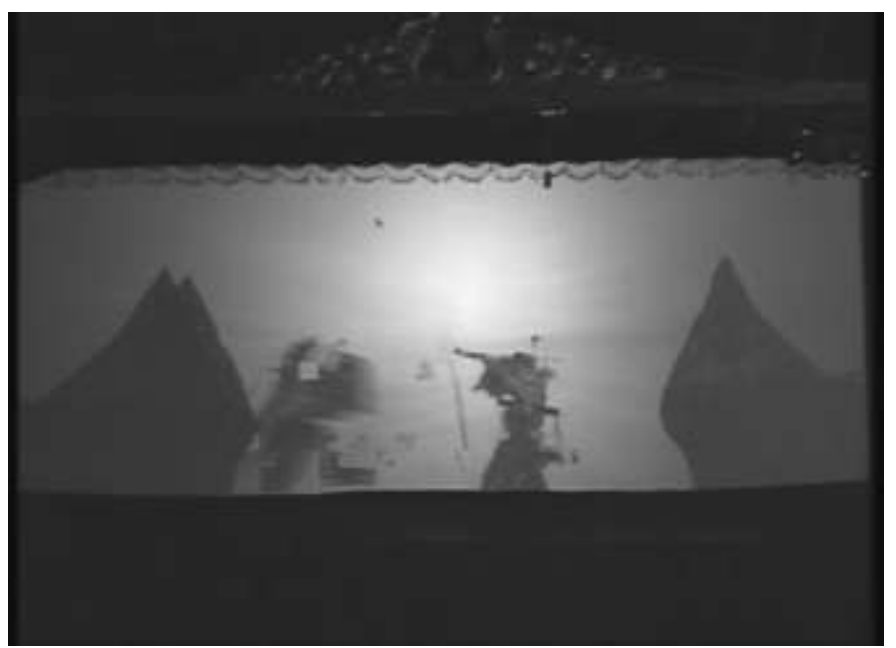

Gambar 26 Gerakan mbucal dalam adegan perang ampyak, sequence 43, transkripsi Parta Krama

Kalau terdapat gerakan membanting beberapa kali, disebut gerakan mbanting binanting. Kemudian ada gerakan yang lain yang biasanya berupa sentakan 
yang disebut cangklet-cengkah. Atau menghantamkan kepala dengan wajah ke arah tanah atau lutut yang disebut nglarak.

Di antara gerakan-gerakan paling agresif di saat perang, adalah ketika seorang tokoh menyerang pihak lawan dengan menggunakan pukulan tangan yang kuat, gerakannya yang cukup agresif ini mirip pencak silat atau karate dan tai chi, disebut ngantem. Pukulan ini menggunakan tangan dengan kaki yang terangkat ke atas untuk memperlihatkan dan menambah kesan adanya kekuatan dan kekerasan. Gerakan yang disebut nyaut, adalah gerakan yang dipakai untuk membebaskan lengan bawah, dan ngepruk merupakan gerakan untuk membebaskan kedua lengan.

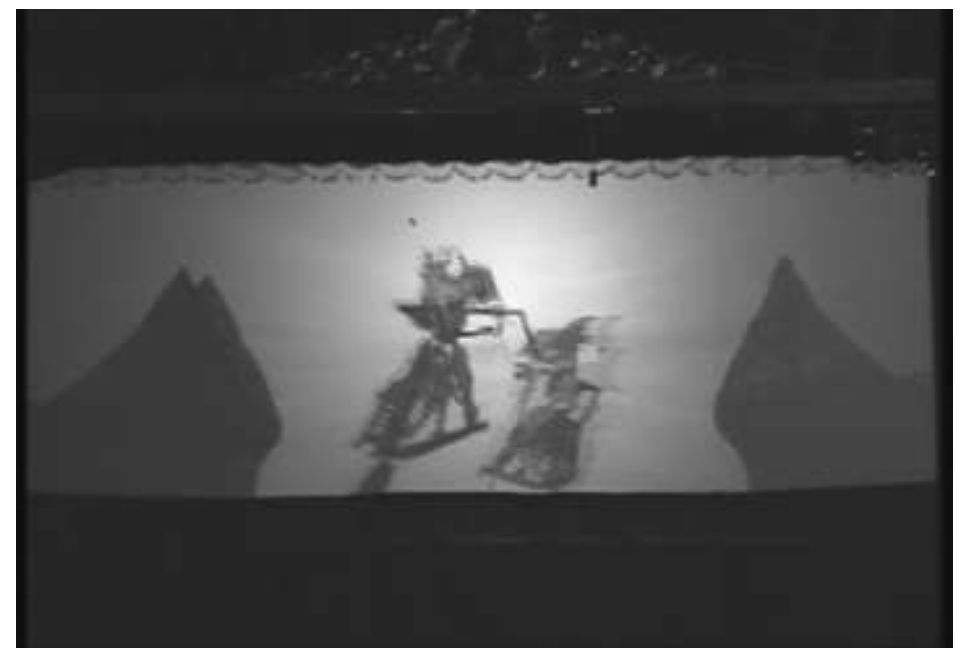

Gambar 27 Gerakan ngantem dalam adegan perang ampyak, sequence 45 transkripsi Parta Krama.

Mungkin sebagian terbesar dari keseluruhan adegan indah dan penuh intrik dalam peristiwa perang tradisional antara para pahlawan muda dengan para raksasa dengan teknik permainan yang luar biasa mempesona terdapat pada adegan perang. Di lingkungan gaya Yogyakarta, biasa disebut dengan perang begal ( merupakan bagian dari pathet sanga, perang antara para pahlawan dan para raksasa, kejadian biasanya di hutan).

Dalam ketentuan perang ini untuk bergerak ke depan dan ke belakang, berputar maju dan mundur, dengan kecepatan gerak yang luar biasa, penyebab adanya gerakan-gerakan dramatis adalah tangkai tuding yang bergerak berputar-putar, dengan kemampuan imajinasi, menghasilkan gerak-gerak dramatis, persis seperti gerak tangan yang akan menyerang musuh, gerak-gerak dramatis dalam adegan ini biasa disebut perang tuding. 


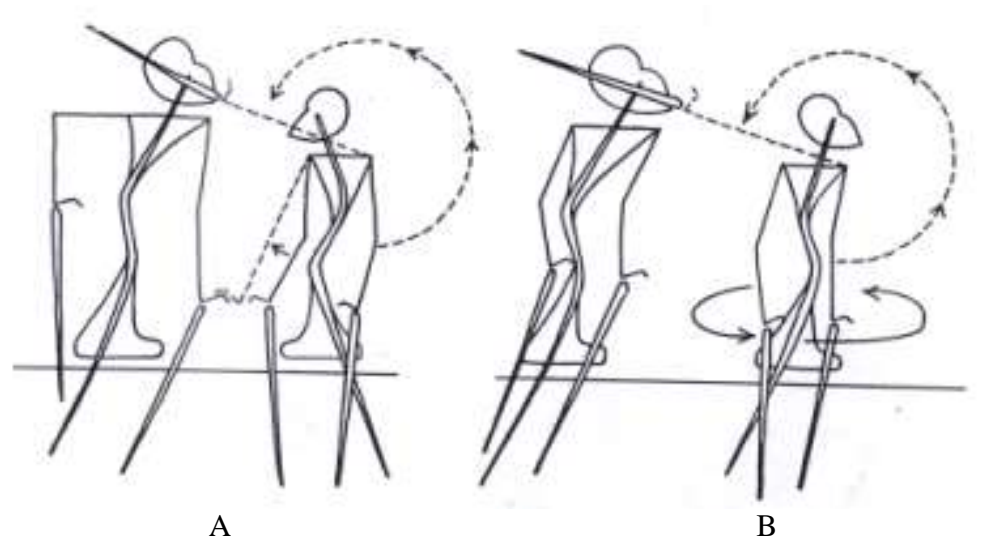

Gambar 28 Dua contoh gerak A dan B dari perang tuding (Roger Long. 1979).

Terdapat tampilan berupa serangan yang tidak terlalu agresif, berupa tamparan yang diarahkan ke wajah dengan posisi saling berdiri yang disebut nempiling, dan apabila pelakunya wanita yang sedang membenci disebut napuk - khusus gerakan ini biasanya dilakukan untuk karakter-karakter tertentu yang biasa melakukan tindakan berlebihan untuk menyatakan gugatan. Terdapat pula karakter-karakter gerak bila gagal mengalahkan musuh dengan menggunakan kemampuan lain yaitu mengerahkan kekuatan tubuhnya dengan menabrak lawan, yang disebut nubruk. Gerakan lain yang hampir mirip dengan nubruk adalah, gerakan melompat tapi langsung mencekal pergelangan tangan lawan disebut melangkah kaping kalih, ada karakter yang melakukannya dengan melompat dan mencekal tangan dari belakang punggung lawan.

Bila menyerbu bersama-sama untuk menyerang tokoh lawan, gerakan ini disebut jeblosan, dan dalam satu gerakan yang spektakuler, dalang dengan ketrampilan tangannya, memainkan adegan tersebut, dan ketrampilan ini disebut jeblosan linton. Gerak lemparan ini suatu kerja yang luar biasa, karena posisiposisi wayang kulit yang dimainkan harus selalu dalam keadaan stabil.

Dalam wayang kulit, tendangan merupakan bentuk lain dari gerakan melempar, berdiri atau jatuh, merupakan teknik yang menunjukkan kekuatan dalam perkelahian. Tendangan yang dikirim dari lantai dasar hingga seolah terbang ke udara. Karena kaki dari wayang kulit tidak mengenal 'bahasa', maka kaki wayang kulit ini dapat menendang sesuka hati, hingga bisa mencapai setinggi lima puluh lima centimeter dari atas tanah. Gerakan ini disebut ndugang, sedangkan gerakan kakinya disebut binten termasuk menendang dengan menggunakan lutut. Sedangkan sebutan nendhang, bila jarak lemparannya pendek. 


\section{Simpulan}

Teori bahasa rupa dapat menjelaskan 'gerak/sebetan' wayang kulit purwa dengan cara menggunakan rangkaian gambar gerak dari satu gambar 'gerak' ke gambar gerak berikutnya, dapat diceritakan secara tekstual tahap demi tahap.

Peranan bahasa rupa gambar-gambar 'diam yang hidup' pada bahasa rupa 'gerak' terdapat pada gambar-gambar tradisi yang berbentuk gambar rangkai, seperti relief Borobudur, Wayang Beber, gambar hias Damarkurung, yang masing-masing memiliki banyak kejadian, rentang waktu, pindah tempat, berbicara dengan gesture, dan terdapatnya kesan ruang, merupakan imaji gerak dalam 'stop motion'. Oleh karena itu bahasa rupa gambar 'diam yang hidup' dapat menjadi dasar teori dari bahasa rupa 'gerak' wayang kulit purwa Yogyakarta.

Tabel 1 Bayangan wayang kulit dalam posisi 'diam'/ditancapkan pada debog pisang sebagai alas panggung 'jagat pewayangan'

\begin{tabular}{|c|c|c|}
\hline No & $\begin{array}{l}\text { Kondisi bayangan wayang pada } \\
\text { 'jagat pewayangan' }\end{array}$ & Makna bahasa rupa 'gerak' \\
\hline 1. & Menghadap dari kiri ke kanan & tuan rumah \\
\hline 2. & Menghadap dari kanan ke kiri & para tamu \\
\hline 3. & 'Diam' bergetar & $\begin{array}{l}\text { gelisah atau bersiap melakukan } \\
\text { tindakan }\end{array}$ \\
\hline 4. & $\begin{array}{l}\text { Semula dari kanan ke kiri, sekarang } \\
\text { tidak tampak }\end{array}$ & ada di luar ruangan \\
\hline 5. & $\begin{array}{l}\text { Semula dari kiri ke kanan, sekarang } \\
\text { tidak tampak }\end{array}$ & ada di dalam ruangan lain \\
\hline 6. & 'Diam' ditancapkan & berpikir, mendengarkan \\
\hline 7. & Saling berhadapan & berdialog \\
\hline 8. & $\begin{array}{l}\text { 'Diam' ditancapkan hanya tangan } \\
\text { sedang } \\
\text { bergoyang/bergerak }\end{array}$ & berbicara \\
\hline 9. & $\begin{array}{l}\text { Tangan mengarah ke tubuh lawan } \\
\text { bicara }\end{array}$ & menenangkan \\
\hline 10. & $\begin{array}{l}\text { Tangan memegang lengan lawan } \\
\text { bicara }\end{array}$ & menenangkan, bersimpati \\
\hline 11. & Tangan bergerak turun & melepaskan tangan \\
\hline 12 & Tangan mengarah ke pinggang & siap untuk berdialog \\
\hline 13. & Tangan di pinggang & tenang berdialog \\
\hline 14. & 'Diam' stabil kembali & diam ditancapkan \\
\hline
\end{tabular}

Rincian gerak wayang dapat dibaca melalui setiap perubahan dari gerak itu pada setiap detik. Melalui peralihan gerak pada setiap detik terdapat perubahan ruang dan waktu yang menyertai gerak beralih dari tiap detik ke detik berikutnya. 
Setiap detik peralihan gerak yang berpindah ruang dan waktu, sehingga dapat dibaca bahasa rupanya melalui cerita gerak itu sendiri.

Peranan bahasa rupa film/TV pada konteks bahasa rupa 'gerak' adalah pada teknik pengambilan gambar atau merekam pagelaran wayang sesuai dengan pagelaran asli. Melalui teknik merekam ini diperoleh pendataan gerak 'stop motion' untuk memperoleh detail 'gerak' setiap detiknya, bagi kepentingan analisis.

Pada pagelaran wayang ditemukan 40 jenis bahasa rupa 'gerak' bayangan wayang kulit purwa, yakni bahasa rupa wayang kulit purwa dalam posisi 'diam'/ditancapkan pada 'jagat pewayangan' dan menemukan bahasa rupa wayang kulit purwa dalam posisi bergerak/ dalam bentuk 'sabetan', 40 jenis bahasa rupa 'gerak' bayangan wayang kulit purwa tersebut dikelompokan dalam tabel 1 dan tabel 2.

Tabel 2 Bayangan wayang kulit dalam posisi 'bergerak'/dalam bentuk sabetan pada 'jagat pewayangan'.

\begin{tabular}{|c|c|c|}
\hline No. & $\begin{array}{c}\text { Kondisi bayangan wayang pada } \\
\text { 'jagat pewayangan' } \\
\end{array}$ & Makna bahasa rupa 'gerak' \\
\hline 1. & Menjadi besar & mulai bergerak \\
\hline 2. & Bentuk besar berpindah ruang dan waktu & bergerak \\
\hline 3. & Bentuk lebih besar lagi & emosi tinggi \\
\hline 4. & $\begin{array}{l}\text { Bentuk masih besar (tidak sebesar sebelumnya) } \\
\text { berpindah ruang dan waktu }\end{array}$ & terus bergerak \\
\hline \multirow[t]{6}{*}{5.} & Bentuk besar bergradasi & bergerak berputar \\
\hline & $\begin{array}{l}\text { a. Bergerak berputar dari kanan ke kiri } \\
\text { (ke depan) }\end{array}$ & $\begin{array}{l}\text { a. supaya terlihat siluet } \\
\text { wajahnya }\end{array}$ \\
\hline & b. Berputar dari kanan ke kiri & b. masuk kembali ke ruangan \\
\hline & - $\quad$ Masuk ke dalam ruang & - menenangkan diri \\
\hline & - $\quad$ Masuk ke dalam ruang & $\begin{array}{l}\text { - bersiap untuk menyerang } \\
\text { (capeng) }\end{array}$ \\
\hline & c. Berputar dari kiri ke kanan & c. sebagai tuan rumah \\
\hline 6. & Bentuk pipih & masih berputar \\
\hline 7. & Di dalam ruang tampak akan maju & bersiap menyerang \\
\hline 8. & Bergerak seolah mundur & bersiap melakukan tindakan \\
\hline 9. & Membesar dan kabur & $\begin{array}{l}\text { bergerak maju dengan cepat, } \\
\text { berlari }\end{array}$ \\
\hline 10. & Bergerak terlihat praba & berputar dari kanan ke kiri \\
\hline 11. & Bergerak berputar & $\begin{array}{l}\text { menghalangi atau akan/mulai } \\
\text { berdialog }\end{array}$ \\
\hline 12. & $\begin{array}{l}\text { Bergerak dan bayangan tangan belakang/muka } \\
\text { bergoyang }\end{array}$ & bersiap untuk menyerang \\
\hline 13. & Bergerak terlihat mahkotanya & masih dalam posisi berputar \\
\hline 14. & Bergerak saling menimpa & berdekapan \\
\hline
\end{tabular}




\begin{tabular}{lll}
\hline No. & \multicolumn{1}{c}{ Kondisi bayangan wayang pada } \\
'jagat pewayangan' & Makna bahasa rupa 'gerak' \\
\hline 15. & Bayangan ditimpa bayangan lain & didekap \\
16 & Bayangan menimpa bayangan lain & mendekap \\
17. & Bayangan mengecil & bergerak saling bertahan \\
18. & Dua bayangan saling bergoyang & dekapan mulai merenggang \\
19. & Dua bayangan mulai berjarak & bergerak untuk berdiri \\
20. & Bentuk menjadi lebih tinggi dari sebelumnya & mengangkat salah satu kaki \\
21. & Bayangan terangkat ke atas & pindah posisi \\
& & sama-sama memindahkan kaki \\
22. & Dua bayangan sama-sama terangkat & memperluas ruang gerak \\
23. & Memindahkan kaki & duduk bersimpuh \\
24. & Bayangan hanya tampak sebatas kaki & terus bergerak \\
25. & Bayangan dalam posisi miring dan lebih besar & bergerak mundur \\
26. & Bayangan tertutup gunungan sebagian demi & \\
& sebagian dari posisi semula & \\
& &
\end{tabular}

Bahasa rupa 'gerak' yang semula merupakan tata ungkapan luar, melalui perpindahan ruang dan waktu, akhirnya dapat dikembangkan melalui bahasa rupa 'gerak' wayang kulit bayangan di saat pergelaran. Melalui rekaman videosequence, karakter gerak setiap tokoh dapat diceritakan, demikian pula dalam setiap penggal waktu terdapat karakter gerak yang dapat diuraikan maknanya.

\section{Referensi}

[1] Kasidi. 1995. Lakon Wayang Kulit Purwa Palasara Rabi. Suntingan Teks dan Analisis Struktural. Tesis magister. Tidak Diterbitkan. Program Studi Sastra Indonesia dan Jawa. Jurusan Ilmu-Ilmu Humaniora, Fakultas Pascasarjana Universitas Gajah Mada, Bab. 1 Pendahuluan hal 2.

[2] Murtiyoso, Waridi, Suyanto, Kuwato, dan Putranto, HT. (2004). Pertumbuhan dan Perkembangan Seni Pertunjukan Wayang. Kundharru Sadhono (Ed). Surakarta: Surya Etnika, hal. 57

[3] Moerdowo. 1963. Reflections Indonesian Arts And Culture. $2^{\text {nd }} . e d$. Soerabaja: Permata, hal. 181-182.

[4] Van Groenendael, V M.C. 1987. Dalang Dibalik Wayang. Jakarta: Pustaka Utama Grafity, hal 23 - 29; 109 - 129; 280 -285; 287-289;

[5] Mulyono, Sri. 1978. Wayang, Asal-usul, Filsafat dan Masa Depannya. Seri Pustaka Wayang 1. Jakarta: Gunung Agung, 9-10; Bastomi, S. 1993. Nilai-nilai Seni Pewayangan. Semarang: Dahara Prize, hal 24-25

[6] Primadi Tabrani. 2005. Bahasa Rupa. Bandung, Kelir. 9; 13; 21; 55; 80$82 ; 91 ; 92 ; 102 ; 103 ; 127 ; 145-148 ; 155-157 ; 173 ; 175-176$

[7] Primadi, ibid, hal 9,13 